\title{
Recycling Waste of Rice Husk to Improve Entrepreneurship Motivation
}

\author{
Fatwa Tentama ${ }^{1}$, Surahma Asti Mulasari ${ }^{2}$, Muchsin Maulana $^{3}$, Rini Anggraeni ${ }^{4}$ \\ ${ }^{1}$ Faculty of Psychology, Ahmad Dahlan University, Yogyakarta, Indonesia \\ ${ }^{2,3}$ Faculty of Public Health, Ahmad Dahlan University, Yogyakarta, Indonesia \\ 4Faculty of Agriculture, Janabadra University, Yogyakarta, Indonesia
}

\begin{tabular}{l} 
Article Info \\
\hline Article history: \\
Received Nov 25, 2015 \\
Revised Jan 24, 2016 \\
Accepted Feb 23, 2016 \\
\hline
\end{tabular}

\section{Keyword:}

Entrepreneurship

Motivation

Rice husk

Recycling Waste

Sample t-test

\begin{abstract}
The farmers in Indonesia have not maximally taken advantage of the existence of rice husk; therefore the huge number of the husk becomes disturbing waste, which spoils environment. The waste of rice husk is potentially capable of improving the farmers' economy amidst the people's lack of knowledge about its potential to commercially produce charcoal briquettes from it, make it a plant growing medium, and change it into manure. This research aims at knowing if the training of recycling waste of rice husk can improve the farmers' entrepreneurship motivation. The subjects of the research were farmers in groups at Bimomartani village, Ngemplak district, Sleman regency. They were 60 participants divided into experimental and control groups. The planned experiment used untreated control group design with dependent pretest and posttest samples. The paired sample t-test and independent sample t-test were used as the techniques of analysis in this research. The result of t-test on paired sample $t$ test for the experimental group resulted in the value of $\mathrm{t}=-6.659$ with $\mathrm{p}=$ $0.000 \quad(\mathrm{p}<0.01)$, which means there was a significant difference of entrepreneurship motivation before and after the training of recycling rice husk. The analysis for Independent sample t-test resulted in the value of $\mathrm{t}=$ 7.411 with $\mathrm{p}=0.000(\mathrm{p}<0.01)$, which means there was a significant difference of entrepreneurship motivation between experimental and control groups. It can be concluded that the training of recycling waste of rice husk was effective in improving the farmers' entrepreneurship motivation.
\end{abstract}

Copyright $@ 2016$ Institute of Advanced Engineering and Science. All rights reserved.

\section{Corresponding Author:}

Fatwa Tentama,

Faculty of Psychology,

Ahmad Dahlan University,

Jalan Kapas No. 9, Semaki, Umbulharjo, Yogyakarta, Indonesia.

Email: fatwa.tentama@psy.uad.ac.id

\section{INTRODUCTION}

Waste, including agriculture waste, is an undesired byproduct, which is not used [1]. Agriculture waste, food processing and household organic waste, including forest plant remnants are materials of biomass [2]. Occasionally, the waste is piled up and contaminates the environment, so that it endangers our health and ecology [3].

Indonesia is very rich of agriculture waste such as coconut shells, coconut coir, palm bunches, hay, rice husk, and corncob. Rice husk is the third largest waste after hay and corncob [4]. The more farmers produce rice the more rice husk they produce. It means that rice husk is still abundant and is potentially environmental contaminant so that it becomes a serious problem to solve.

It is known from observation and interview at Bimomartani village that rice husk from rice mills in the region is discarded and very often is burned. Few people take advantage of it such as for furnace bricks, 
putting it in hencoop, making it washing ash, hearth, and so forth, which is less maximum. Furthermore, the unprocessed waste contaminates the environment.

The main point of the problem of rice husk lies in the farmers' less desire and low motivation to exploit it and make it useful commercial materials suitable for entrepreneurship. Due to the above mentioned facts, it becomes necessary to improve their knowledge and skills to take advantage of the great number of rice husk. The entrepreneurship motivation is surely badly needed to realize attitudes and activities of entrepreneurship. This will lead to improve the farmers' economy and overcome environmental problems.

Results of interview with some farmers at Bimomartani village indicate that they are not interested in entrepreneurship and they keep feeling comfortable in farming. This is due to their lack of seeing possibilities to carry out business, being afraid of failure, feeling less confident of their capacity and having less capital. They should be assured that they are capable of conducting entrepreneurship.

Oosterbeek, et al [5] point out that decision makers in the developed countries feel necessary to include entrepreneurship to raise to higher economy development of the countries. Besides the economy advantages of the countries, entrepreneurship makes it possible for the farmers to be creative and independent. This area may open the chance to improve the farmers' economy if they can see and take advantage of it.

The mechanism to realize entrepreneurship normally starts from the ideas to carry out entrepreneur activities, where entrepreneur opens possibilities to open commercial chances. These basic ideas are called vision [6]. Vision encourages motivation through desired result expectations in the future [7].

Motivation is the main capital for entrepreneur. Because of motivation an individual is encouraged to carry out efforts in relation to making use of rice husk waste and he will eventually develop them as a business chance, which can raise selling products to improve the farmers' economy as well as to overcome environment problems. Ryan and Deci [8] point out that motivation is the core of biology, cognitive, social regulation. Motivation involves energy, desires, persistence activation, and motives. Louart explains that motivation reveals as a connection between internal energy activation and those ones expressed in business creation [9].

The research on entrepreneurship motivation becomes an important aspect in entrepreneurship process [10]. In order to understand more entrepreneurship motivation, we adopt Louart's approach [11] where motivation is considered as the relationship between external activities and the transfer of energy towards business creation. Riyanti [12] clearly explains that entrepreneurship motivation is a strong technical impulse in an individual to prepare himself to work, having awareness of business so that he puts more attention in it and then he is voluntarily involved in entrepreneur activities independently. Moreover, he is confident, future oriented to succeed in the area of business considering his capacity, strength, and skills and right planning. Without entrepreneurship motivation there will be no desire to learn and to be creative moreover to be productive.

Entrepreneurship motivation can also influence entrepreneurship behavior in three complementary ways: firstly the impact of individual choice, which covers behavioral tendency and action intensity in entrepreneur, secondly the importance of individual action, and thirdly the eagerness of action to achieve the objectives [13]. Different motivation may also affect entrepreneurship processes such as man's perception on possible business risks and chances, which in the end affect his decision to carry out business [14].

Researches on how to improve entrepreneurship motivation on farmers can be carried out. Improving the farmers' entrepreneurship motivation can be done through training to improve their knowledge and skills in recycling rice husk waste so that they can change it into useful products for either self-fulfillment or for commercial purposes such as ash briquettes, planting medium, or manure. Through the training farmers can understand practically the entrepreneurship techniques and motivation.

The experimental research through training in recycling rice husk waste is carried out within six sessions, which refer to the fulfillment of entrepreneurship motivation pointed out by Meredith [15] i.e. having the capacity to see business chances, behaving as a leader, taking initiative to innovate and to be creative, being hard working, having wide perspective towards mission and vision, and daring to take risks. The first session is filling out entrepreneurship motivation pretest-scale. In this phase, the researcher tried to measure the degree of the subjects' entrepreneurship motivation before the training. How to fill out the forms and their understanding on each scale items are explained. The second session is the training on improving environmental consciousness. The subjects of the research are motivated to see, realize, and then to take advantage business chances managing environmental waste to improve their future.

The third session is the training of entrepreneurship motivation. This training aimed at implementing the spirit for hardworking in achieving objectives, and at implementing good behavior towards encouraging and directing others with responsibility to improve business. The forth session is the training of recycling rice husk waste into ash briquettes, planting medium, and manure. This session aimed at improving the farmers' skill and creativity in recycling rice husk waste into ash briquettes, planting medium, and manure so that they

IJPHS Vol. 5, No. 1, March 2016 : $75-83$ 
could produce new quality products, which were useful and marketable. The fifth session was entrepreneurship training. The knowledge and understanding to be a self-confident, conflicting entrepreneur, having wide perspectives, who dares taking a risk, were implemented. The sixth session was data collecting of post-test scale and monitoring and evaluation of internal researchers. The researchers measured the subjects' entrepreneurship motivation after the training and carried out monitoring and evaluation towards the subjects.

The objectives of the research was to know how affective the training on recycling rice husk waste it was to improve the farmers' entrepreneurship motivation in Bimomartani village, Ngemplak district, Sleman Regency, Yogyakarta special province. The research implication for the farmers was that the training on recycling rice husk into ash briquettes, planting medium, and manure became a factor to improve the farmers' entrepreneurship motivation and as result it could constitute the farmers' behavior to carry out business and could impact their raise of economy. Furthermore it could solve some environmental problems. The local government could take advantage of the program.

\section{RESEARCH METHOD}

\subsection{Research subjects}

The subjects of the research were 60 participants of farmers in Bimomartani, Ngemplak, Sleman, Yogyakarta consisting of experimental and control groups. Each group consisted of 30 participants. The selection of experimental and control group members was done without random technique but with purposive one considering their residential status, occupation as farmer, their incapability of recycling rice husk for business.

\subsection{Measurement instruments}

The scale used to measure the farmers' entrepreneurship motivation referred to any aspects of entrepreneur proposed by Meredith [15] i.e. the ability to see work chances, having leadership behavior, having initiatives to innovate and to be creative, hardworking, having wide perspectives on vision and mission, and daring to take a risk.

\subsection{Validity and reliability of the instruments}

Scale items, which were completed, were then selected with the consideration of correlation coefficient of total items corrected as (rxy). The entrepreneurship motivation scale used limit of 0.25 so that items showing different index greater or the same as 0.25 worth filling in the research scale. The research scale of entrepreneurship motivation consisted of 36 items valid with correlation coefficient at the lowest level 0.252 and the highest level 0.771 . The reliability test of entrepreneurship motivation used the formula alpha $(\alpha)$ from Cronbach and only valid items were included. The entrepreneurship motivation scale showed reliability coefficient of 0.941 which meant reliable and could be used as instrument for data collection.

\subsection{Research design}

The type of the research was a quasi experimental research, whose control towards the extra variable was not tight and the choice of sample was not random. This was due to the fact that pure experimental research design was not possible to carry out [16].

The experimental research design was untreated control group design with dependent pretest and posttest samples. That is to say the experimental research design used experimental and control groups by means of giving them pre-test and post-test. Referring Shadish \& Cook [17], the experimental group was given a training on how to recycle the waste of rice husk and the control group was not did it [17]. The results of both pre-tests and post-tests were then compared to know the degree of entrepreneurship motivation of the farmers. Thus, the influence of the training was known.



Figure 1. Research design 




\subsection{Research instrument and material}

The instruments and the materials of the research included the followings:

1. Entrepreneurship motivation scale.

2. Rice husk waste.

3. Hand outs.

4. Stove.

5. Container with its lid.

6. Matches.

7. Plate.

8. Water.

9. Maizena powder.

Supporting facilities:

1. A room for training

2. Audio-visual equipments: Liquid Crystal Display, microphone, and loud speaker.

3. Video player.

4. Video recorder and camera.

\subsection{Experiment procedure}

The research was done in three phases i.e. the preparation, the execution and the report of the research. The preparation phase was carrying out a field survey, making a field study, an observation and an interview towards the subject of the research which all of them lasted a month. This phase included carrying out literature study in relation with the observation and carrying out an interview, documenting findings in the field and then followed by making the research proposal. Before executing the research, the researcher set the measurement instrument of the research i.e. entrepreneurship motivation scale and preparing the training module or hand outs. The scale of the experiment was then used as the research measurement. The last phase of the research was getting permits for the research, making coordination with the farmer group leaders on how to follow the procedure and execute the research including socializing training programs to the participants.

At the beginning of the research, the researcher carried out a try out on entrepreneurship motivation scale to get a valid and reliable instrument. The scale consisted of 36 items. It was given to 30 participants from whom the data of the entrepreneurship motivation were collected and then analyzed by means of Statistical Product and Service Solutions (SPSS) 17.0. After that the pre-determined characteristic selected participants were grouped into two the experimental and the control groups. The experimental group was the group, which would be given the training while the control group were the group which got no treatment.

The execution of the research was marked by the distribution of the prepared research scale (pretest) for both of the experimental and control groups. Prior to the distribution, the participants were explained about the procedure of filling in the scale. The whole sessions covered:

Session 1. Filling in the entrepreneurship motivation scale for pre-test. In this session the participants were given instructions of how to fill in the scale and of understanding the items of the scale.

Session 2. The training of environmental awareness culture. The participants 'environmental awareness to see, understand and to take advantage of business chances around them was implemented.

Session 3. The training of entrepreneurship motivation. This aimed at encouraging and stimulating continuous hard work desire to achieve business goals. In the end they would be capable of selfdirecting, self-motivating, and in the end be responsible to improve business.

Session 4. The training of recycling rice husk into ash briquettes, planting medium, rice seeding medium and manure as useful and quality products for business.

Session 5. The entrepreneurship training. The knowledge and understanding to be a strong, risk taking entrepreneur with wide perspective and good vision were introduced.

Session 6. The post-test data collection of the entrepreneurship motivation scale was done by the researcher. The researcher measured the participants' entrepreneurship motivation scale after the training and monitored the developments of the participants' entrepreneurship motivation. 


\subsection{Data analysis}

To analyze the data this research used a parametric statistical method. The technique for the analysis employed t-test i.e. the paired t-test samples and independent t-test samples. The former samples were used to know if there was a level of difference in entrepreneurship motivation before and after the training of the experimental group. They were also used to know the level of difference in entrepreneurship motivation between the experimental and control groups. All data computational analyses were done by means of SPSS 17.00 programs for Windows.

\section{RESULTS AND ANALYSIS}

\subsection{Paired sample t-test}

\subsubsection{The normality test}

According to the result of the normality test from Table 1, it was known that the significant value of the (2-tailed) pre-test was $(0.742)$ and the post-test was $(0.371)$ where $p>0.05$, so that each data was normally distributed. It means there was no difference of distribution score between the samples and the population. In other words, the samples represented the population.

Table 1. The Result of Normality Test

\begin{tabular}{llcc}
\hline \multicolumn{3}{c}{ One-Sample Kolmogorov-Smirnov Test } \\
\hline & & Pretest & Posttest \\
\hline $\mathrm{N}$ & & 30 & 30 \\
Normal Parameters & & 108.00 & 112.47 \\
& Mean & 6.888 & 6.263 \\
Most Extreme Differences & Std. Deviation & .124 & .167 \\
& Absolute & .112 & .117 \\
& Positive & -.124 & -.167 \\
& Negative & $\mathbf{. 6 8 1}$ & $\mathbf{. 9 1 6}$ \\
Kolmogorov-Smirnov Z & & $\mathbf{. 7 4 2}$ & $\mathbf{. 3 7 1}$ \\
\hline Asymp. Sig. (2-tailed) & & & \\
\hline
\end{tabular}

a. Test distribution is Normal.

b. Calculated from data.

Table 2 and Table 3 show the result of t-test i.e. the paired t-test result of the experimental group showed t-value -6.659 where $\mathrm{p}=0.000(<0.01)$, which means very significant or there was a very significant difference of entrepreneurship motivation before and after the training of recycling rice husk. The degree of entrepreneurship motivation after the training was higher than before (the means of pretest score: 108 and the means of post-test score was: 112.47)

Table 2. Descriptive Statistics

\begin{tabular}{cccccc}
\hline \multicolumn{6}{c}{ Descriptive Statistics } \\
\hline & N & Mean & Std. Deviation & Minimum & Maximum \\
\hline Pre-test & 30 & $\mathbf{1 0 8 . 0 0}$ & 6.888 & 95 & 119 \\
Post-test & 30 & $\mathbf{1 1 2 . 4 7}$ & 6.263 & 101 & 123 \\
\hline
\end{tabular}

Table 3. Paired Samples Test Result

\begin{tabular}{|c|c|c|c|c|c|c|c|c|}
\hline \multicolumn{9}{|c|}{ Paired Samples Test } \\
\hline \multicolumn{6}{|c|}{ Paired Differences } & \multirow{3}{*}{$\mathrm{t}$} & \multirow{3}{*}{$\mathrm{df}$} & \multirow{3}{*}{$\begin{array}{c}\text { Sig. } \\
(2 \text {-tailed })\end{array}$} \\
\hline & \multirow[t]{2}{*}{ Mean } & \multirow{2}{*}{$\begin{array}{c}\text { Std. } \\
\text { Deviation }\end{array}$} & \multirow{2}{*}{$\begin{array}{l}\text { Std. Error } \\
\text { Mean }\end{array}$} & \multicolumn{2}{|c|}{$\begin{array}{l}\text { 95\% Confidence Interval of the } \\
\text { Difference }\end{array}$} & & & \\
\hline & & & & Lower & Upper & & & \\
\hline Pair 1 Pretest - Posttest & -4.467 & 3.674 & .671 & -5.839 & -3.095 & -6.659 & 29 & .000 \\
\hline
\end{tabular}




\subsection{Independent sample T-Test}

\subsubsection{Normality test}

Based on the results of normality test analysis on Table 4, it was known that the significant value (2tailed) of the experimental group was 0.869 and the significant value of the control group was 0.783 where p $>0.05$ so that each data was normally distributed. It means there was no difference in the score of distribution between the samples and the population. In other words the samples represented the population.

Table 4. Normality Test Result

\begin{tabular}{llccc}
\hline & \multicolumn{2}{c}{ One-Sample Kolmogorov-Smirnov Test } & \\
\hline $\mathrm{N}$ & & $\begin{array}{c}\text { Experimental } \\
\text { Group }\end{array}$ & Control Group & $\begin{array}{c}\text { Entrepreneurship } \\
\text { Motivation }\end{array}$ \\
\hline \multirow{2}{*}{ Normal Parameters } & & 30 & 30 & 60 \\
& Mean & 4.47 & -1.90 & 1.28 \\
Most Extreme Differences & Std. Deviation & 3.674 & 2.940 & 4.603 \\
& Absolute & .109 & .120 & .088 \\
& Positive & .109 & .085 & .088 \\
& Negative & -.106 & -.120 & -.056 \\
Kolmogorov-Smirnov Z & & $\mathbf{. 5 9 7}$ & $\mathbf{. 6 5 6}$ & .683 \\
Asymp. Sig. (2-tailed) & & $\mathbf{. 8 6 9}$ & $\mathbf{. 7 8 3}$ & .740 \\
\hline
\end{tabular}

a. Test distribution is Normal.

b. Calculated from data.

\subsubsection{Homogeneity test}

Table 5 shows the results of homogeneity test shows levene statistic $=0.988$ and $\operatorname{sig}=0.324(\mathrm{p}>$ 0.05). Based on the analysis, it is said that the variants were homogeny, which means the two sample groups came from the population having the same variants.

Table 5. Homogenity Test Result

\begin{tabular}{cccc}
\hline \multicolumn{4}{c}{ Test of Homogeneity of Variances } \\
\hline \multicolumn{4}{c}{ Entrepreneurship Motivation } \\
\hline Levene Statistic & df1 & df 2 & Sig. \\
\hline .988 & 1 & 58 & $\mathbf{. 3 2 4}$ \\
\hline
\end{tabular}

Table 6 and Table 7 show the results of t-test analysis of independent sample t-test on experimental and control groups by means of gain score. From the analysis it is known that t-value: 7.411 where $\mathrm{p}=0.000$ $(\mathrm{p}<0.01)$. it means very significant. Thus, there was a great difference in the level of entrepreneurship motivation between experimental and control groups. The means of score M: 4.47 for experimental group and M: -1.90 for the control group. The mean of experimental group was higher than the mean of the control group.

Table 6. Descriptive Statistics

\begin{tabular}{ccccccc}
\hline \multicolumn{7}{c}{ Descriptive Statistics } \\
\hline N & Mean & Std. Deviation & Std. Error & Minimum & Maximum \\
\hline By Training & 30 & $\mathbf{4 . 4 7}$ & 3.674 & .671 & -5 & 12 \\
Without Training & 30 & $\mathbf{- 1 . 9 0}$ & 2.940 & .537 & -8 & 4 \\
Total & 60 & 1.28 & 4.603 & .594 & -8 & 12 \\
\hline
\end{tabular}


Table 7. Independent Samples Test Result

\begin{tabular}{|c|c|c|c|c|c|c|c|}
\hline \multicolumn{8}{|c|}{ Independent Samples Test } \\
\hline & & Levene's Test for & \multicolumn{5}{|c|}{ t-test for Equality of Means } \\
\hline & & $\mathrm{F}$ & $\mathrm{t}$ & df & $\begin{array}{l}\text { Sig. }(2- \\
\text { tailed) }\end{array}$ & $\begin{array}{c}\text { Mean } \\
\text { Difference }\end{array}$ & $\begin{array}{l}\text { Std. Error } \\
\text { Difference }\end{array}$ \\
\hline \multirow{2}{*}{$\begin{array}{l}\text { Entrepreneur-ship } \\
\text { Motivation }\end{array}$} & Equal variances assumed & .988 & 7.411 & 58 & .000 & 6.367 & .859 \\
\hline & $\begin{array}{c}\text { Equal variances not } \\
\text { assumed }\end{array}$ & & 7.411 & 55.341 & .000 & 6.367 & .859 \\
\hline
\end{tabular}

From the above analysis it is known that the hypothesis of the research, which says that the training of recycling rice husk affects the improvement of the farmers' entrepreneurship motivation, is accepted.

\subsection{Analysis}

The results of t-test analysis for paired t-test samples of experimental group and independent sample t-test for both experimental and control groups by means of gain score showed that the training of recycling rice husk was effective and affected the improvement of the farmers' entrepreneurship motivation.

The people in Bimomartani were mostly farmers. The fertile land produces abundant rice. The rice husk waste piles up. The raw material to be recycled, which is therefore great in number, easy to get, and relatively cheap attracts the people to carry out business.

The research on entrepreneurship motivation becomes an important aspect in entrepreneurship [10]. Louart [11] argues that entrepreneurship motivation is featured as the relationship between internal activation and energy release towards business creation.

Riyanti [12] says that entrepreneurship motivation is a strong technical impulse in an individual to prepare himself to work, which stimulates entrepreneurship awareness so that he will pay much attention and will be more eager to carry out independent business, will be more self-confident, will be future oriented to a successful businessman in the field considering his ability, strength, and skill with organized plan.

The effort to improve Bimomartani farmers' entrepreneurship motivation began with the training of recycling rice husk into charcoal briquettes, planting medium, and manure for self-fulfillment or for sale. By the training it is hoped that the farmers' knowledge, attitude, skill to carry out business will improve especially in relation to the making use of rie husk.

By the knowledge, attitude, and the skill to become entrepreneur, it is expected that they will be more self-confident, initiative, creative than before the training. The knowledge and skill also improve the farmers' point of view. Their perspective in making use of rice husk waste can improve their entrepreneurship motivation.

There were some advantages obtained from the training of recycling rice husk into charcoal, planting medium, and manure so that it could stimulate the farmers to be entrepreneurs. Farm waste called biomass is potentially changed into energy [4]. One way to overcome to problem of farm waste is to change biomass into charcoal briquettes [18].

The making of charcoal briquettes could improve their income and could solve environmental problems [19]. The charcoal from the farm waste can be commercially sold to replace firewood or coal for cooking, heating, or for rural or urban industry [20]. The process of making the charcoal briquettes is economically cheap and applicable for rural people especially for middle and low class and it prevents from disease vector [21]. They also point out that the charcoal briquettes produce cheap alternative energy [21]. The advantage of charcoal according to Timothy [22] is that the charcoal as source of cooking energy is cheaper than kerosene, gas and even firewood. Oroka and Thelma [23] say that the briquettes substitute petrol, firewood, coal for household and small industry. Kuti [24] says that is time for petrol and LPG consumers to reduce them due to the limited availability.

The recycle of biomass waste into charcoal briquettes can give some advantages among others: Briquettes are cheaper than coal or oil, briquettes have high burning efficiency, and it provides additional income to farmers and creates jobs [25]. The briquettes produce more heat, environmentally friendly, easy to use, and require less space [23]. Nevertheless the making of the charcoal is not relatively easy due to many factors such as the kinds of biomass, size, and density [26]. Apart from the size of the particle the kinds of sizing also influence the quality of the briquettes [27]. Combining with other raw materials is of course considered to be able to improve the quality and reduce the defect of the raw material [28].

Besides the training to recycle rice husk waste into charcoal, it also provides the possibility to change it into planting medium and organic fertilizer. In order to realize these things the rice husk waste is changed into charcoal. As a planting medium, it makes the soil fertile due to the charcoal construction, which allows the plants' roots to penetrate the soil. This is because of the charcoal pores as planting medium. The 
pores are useful to absorb water, air, and fertility substances. These things are in accordance with Tentama et al., [29] statement which says rice husk waste can be changed into a plating medium and organic fertilizer.

The rice husk waste is also advantageous to manure. Giving manure is an effort farm intensification to improve fertility elements needed by the plants to raise quality produce. Nowadays, the use of farm waste is widespread. This is because of the availability of the waste. Giving ash from rice husk can stimulate the growth and prevent from pest. The rice husk farm waste is fibrous material containing cellulose, lignin, hemicellulose and when burned it will produce ash with high silica (87\% - 97\%) and contains N $1 \%$ and $\mathrm{K}$ $2 \%$. The role of kalium in the charcoal can strengthen the plant so that the leaves and flowers will not fall off. It can regulate respiration, transpiration, the work of enzymes and maintain the osmosis.

\section{CONCLUSION}

Based on the analysis, it can be concluded that the training of recycling rice husk waste can improve the farmers' entrepreneurship motivation. This was indicated by the difference degree of the farmers' entrepreneurship motivation before and after the training of the experimental group and the difference of the degree of entrepreneurship motivation between experimental and control groups.

The researcher suggests that: the result of the research showed that the training of recycling rice husk waste could improve the farmers' entrepreneurship so that it is recommendable to be one of the ways to empower people in taking advantage of the rice husk waste, which is rich in Sleman regency. For the other researchers, who are interested in this area, are advised to make follow up measurement to see the long term effect of the training.

\section{REFERENCES}

[1] Dwivedi, PR., Augur, MR., Agrawal, A., "A study on the effect of solid waste dumping on geo-evironment at bilaspur", American International Journal of Research in Formal, Aplplied and Natural Sciences, vol/issue: 6(1), pp. 86-90, 2014.

[2] Tembe, ET., Adetogun, AC., Agbidye, FS., "Density of briquettes produced from bambara groundnut shells and it's binary and tertiary combinations with rice husk and peanut shell", Journal on Natural Sciences Research, vol/issue: 4(24), pp. 21-26, 2014.

[3] Olajedi, TJ., Oyetunji, OR., "Investigation into physical and fuel characteristics of briquettes produced from cassavas and yam peels", Journal of Energy Technologies and Policy, vol/issue: 3(7), pp. 40-47, 2013.

[4] Rohmah, N., Pikra, G., Salim, A., "Organic rankine cycle system prelimenary design with corn cob biomass waste burning as heat source", International Conferance on Sustainable Energy Engineering and Aplication. Energy Procedia, vol. 32, pp. 200-208, 2013.

[5] Oosterbeek, H., Van Praag, M., Ijsselstein, A., "The impact of enterpreneurship education on entrepreuneurship skills and motivation", Europian Economic Review, vol. 54, pp. 442-454, 2009.

[6] Shane, S., Locke, EA., Collins, CJ., "Entrepreneurial motivation", 2003. in/files/documents/6Entrepreneurial motivation.pdf.

[7] Leon, JA., Gorgievski, M., Lukes, M., "Teaching psychology of entrepreneurship", 2008. http://portal.uned.es/pls/portal/docs/PAGE/UNED_MAIN/LAUNIVERSIDAD/UBICACIONES/02/DOCENTE/JU AN_ANTONIO_MORIANO_LEON/TEACHING\%20PSYCHOLOGY\%200F\%20ETREPRENEURHIP\%202008 .PDF.

[8] Ryan, RM., Deci, EL., "Self-determination theory and the facilitation of intrinsic motivation, social development, and well-being", American Psychologist, vol. 55, pp. 68-78, 2000.

[9] Estay, C., Durrieu, F., Akhter, M., "Entrepreneurship: From motivation to start-up", J Int Entrep, vol. 11, pp. 243267, 2013.

[10] Carsrud A., Brannback, M., "Entrepreneurial motivations: what do we still need to know?", Journal Small Bus Manag, vol. 49, pp. 9-26, 2011.

[11] Louart, P., "Motivation”, in Simon Y., Joffre P. (eds), “Encyclopedie de gestion. 2nd edn”, Paris Economica, 1997.

[12] Riyanti, B., "Entrepreneurship from the standpoint of personality psychology", Jakarta, PT. Gramedia Widiasarana Indonesia, 2003.

[13] Braga, JC., Proenca, T., Ferreira, MR., "Motavitions for social entrepreneurship - Evidences From Portuga", Review of Applied Management Studies, vol/issue: 28(11), pp. 1-11, 2015.

[14] Shane, S., Venkataraman, S., "The promise of entrepreneurship as a field of research", Academy of management review, vol/issue: 25(1), pp. 217-226, 2000.

[15] Suryana, "Entrepreneurship", Jakarta, Salemba Empat, 2003.

[16] Mayers, A., Hansen CH., "Experimental psychology (Ed. Ke-4)", New York, Wadsworth Thomas Learning, 2002.

[17] Shadish, WR., Cook, TD., "Experimental and quasi-experimental design for generalized causal inference", Boston, Houghton Mifflin Company, 2002.

[18] Francis, AC., Akhijith, A., Alexander, A., Baby, B.K., "Broquette Burner”, International Journal of Research in Engineering and Technology, vol/issue: 3(6), pp. 67-71, 2014. 
[19] Birwatkar, VR., Khandeted, YP., Mohod, AG., Dhande, KG., "Physical and thermal properties of biomass briquetted fuel", Ind.J.Sci.Res.and Tech, vol/issue: 2(4), pp. 55-62, 2014.

[20] Akowuah, JO., Kemausuor, F., Mitchual, SJ., "Physico-chemical characteristics and market potential of sawdust charchoal briquette", International Journal of Energy and Environmental Engneering, vol/issue: 3(20), pp. 1-6, 2012.

[21] Raju, CAI., Jyoth, KR., Satya, M., Praveena, U., "Studies on development of fuel briquettes for household and industrial purpose", International Journal of Research in Engineering and Technology, vol/issue: 3(2), pp. 54-63, 2014.

[22] Timothy, YA., "Major Role of Locally Made Charcoal Business in Promoting Entrepreneurial Status in Nigeria", Mediterranean Journal of Social Sciences, vol/issue: 4(12), pp. 139-146, 2013.

[23] Oroka, FO., Thelma, E., "Fuel briquettes from water hyacinth-cow dung mixture as alternative energy for domestic and agro-industrial application", Journal of Energy Tecnologies and Policy, vol/issue: 3(6), pp. 56-62, 2013.

[24] Kuti, OA., "Performance of composite sawdust briquette fuel in a biomass stove under simulated condition", AUJ.T, vol/issue: 12(4), pp. 284-288, 2009.

[25] Maninder, Kathuria, RS., Grover, S., "Using Agricultural Residues as a Biomass Briquetting: An Alternative Source of Energy", Journal of Electrical and Electronics Engineering, vol/issue: 1(5), pp. 11-15, 2012.

[26] Mitchual, SJ., Mensah, KF., Darkwa, N., "AEffect of species, perticle size and compacting pressure on relaxed desnsity and compressive strength of fuel briquettes", International Journal of Energy and Environmental Engneering, vol/issue: 4(30), pp. 1-6, 2013.

[27] Zakari, IY., Ismaila, A., Sidiq, U., Nasiru, R., "Investigation on effects of addition on binder and particle size on high calorific value of solid biofuel briquettes", Journal of Natural Sciences Research, vol/issue: 3(12), pp. 30-35, 2013.

[28] Supatata, N., Buates, Hariyanont, P., "Characterization of fuel briquettes made from sewage sludge mixed with water hyacinth and sewage sludge mixed with sedge", International Journal of Environment Science and Development, vol/issue: 4(2), pp. 179-181, 2013.

[29] Tentama, F., Maulana, M., Anggraeni, R., Mulasari, SA., "Science and Technology for Rural Communities", Yogyakarta, Aswaja Pressindo, 2014. 